\title{
Knowledge, Attitude and Practice of School Health Programme among Head Teachers of Primary Schools in Egor Local Government Area of Edo State, Nigeria
}

\author{
${ }^{1}$ G. E. Ofovwe and ${ }^{2}$ A. N. Ofili \\ ${ }^{1}$ Departments of Child Health and ${ }^{2}$ Community Health, School of Medicine, College of Medical Sciences, \\ University of Benin, Benin City, Nigeria \\ Reprint requests to: G. E. Ofovwe, Department of Child Health, University of Benin Teaching Hospital, \\ P. M. B. 1111, Benin City, Nigeria.E-mail: ofovwegabriel@yahoo.com
}

\begin{abstract}
Background: School health program (SHP) is an important component of the overall health care delivery system of any country. In developing countries such as Nigeria where infant and early childhood mortality is high its importance cannot be overemphasized. For this reason and the recent action plan of the Federal Government of Nigeria concerning SHP, the knowledge, attitude and practice of SHP among head teachers of primary schools in a Local Government Area in Nigeria was evaluated.

Methods: A pre-tested questionnaire designed to evaluate the knowledge attitude and practice of SHP by the researchers was administered by assistants to 133 head teachers of 104 private and 29 public primary schools in Egor Local Government Area of Edo State, Nigeria. The School premises were also inspected to check provision of pipe borne water, sick bay, toilet facilities and the adequacy of the school environments among other things.

Results: None of the head teachers had adequate knowledge of SHP. $93.1 \%$ from private compared to $48.3 \%$ from public schools had poor knowledge of SHP $\left(\chi^{2}=56.86, p<0.05\right)$. A favorable attitude was demonstrated by all the teachers. Up to $40.4 \%$ of private compared to $31.0 \%$ of public schools have SHP. Overall $27.7 \%$ of the schools had no toilet facility, $33.3 \%$ had pit latrine while $40.0 \%$ had water closet. Only $25.6 \%$ had hand washing facilities. Regarding health services, $51.0 \%$ of private schools compared to $27.6 \%$ of public schools perform medical inspection of the pupils. Similarly $39.4 \%$ private compared to $3.4 \%$ public schools have sick bay $\left(\chi^{2}=11.11 ; \mathrm{p}<0.05\right)$. A total of $16.5 \%$ of the schools undertake medical screening of food handlers/vendors, while $20.2 \%$ private compared to $3.4 \%$ public schools screen food handlers/vendors $\left(\chi^{2}=4.47 ; \mathrm{p}<0.05\right)$.

Conclusion: The poor status of SHP in Nigeria may be attributed to failure of policy enunciation, poor primary health care base and lack of supervision.
\end{abstract}

Key words: School health, knowledge, attitude, practice, head teacher

\section{Resumé}

Introduction: Le programme de sante scolaire (PSS) est une compasante importante des services medicaux de n'importe quel pays. Dans des pays en voie de developpment tel le Nigéria oń le taux de la mortalité dans la petite enfance est élevé, son importance ne peut pas être exagérer. Pour cette raison - ci et suivant le nouveau plan d'action du Gouvernement Fédéral du Nigéria concernant le PSS, la connaissance, les attitudes et l'usage de PSS parmi les directeurs des écoles primaires dans un quartier de gouvernment locale au Nigéria ont été évalués

Méthode: Un questionnaire eprouvé conçu par les chercheurs pour évaluer la connaissance, les attitudes, et l'usage de PSS a été administré par des assistants à 133 directeurs de 104 écoles privées et 29 écoles publiques. Les locaux des écoles ont été également inspectés pour contrôler la mise à disposition de l'eau potable, des infirmeries, des toilettes, et la propreté des environnements des écoles.

Résultats: Aucun des directeurs n'avaient de connaissance suffisant de PSS 93.1\% des directeurs d'écoles privées par rapport à $48.3 \%$ de ceux des écoles publiques avaient une connaissance limité de PSS $\left(\chi^{2}=56.86, p<0.05\right)$. Tous les proffesseurs ont manifestés un attitude favorable. Jusqu'a $40.4 \%$ des écoles privées par rapport à $31.0 \%$ des écoles publiques implémentent le PSS. D'ensemble, $27.7 \%$ des écoles n'avaient pas de toilletes ; $33.0 \%$ avaient des fosses tandis que $40.0 \%$ avaient le W/C. Seulement $25.6 \%$ de tous les écoles avaient des lavabos. Concernant les services médicaux, 51.0\% des écoles privées par rapport à $27.6 \%$ des écoles publiques procèdent à l'inspection medicale de ses élèves. De 
même $39.4 \%$ des écoles privées par rapport à 3.4\% des écoles publiques ont des infirmeries $\left(\chi^{2}=11.11 ; \mathrm{p}\right.$ $<0.05)$. Au total, $16.5 \%$ des écoles entreprendent des examens de dépistage des vendeurs de la nourriture, tandis que $20.2 \%$ des écoles privées par rapport à $3.4 \%$ des écoles publiques entreprendent des examens de dépistage des vendeurs de la nourriture $\left(\chi^{2}=4.47 ; \mathrm{p}<0.05\right)$.

Conclusion : La mauvaise situation de PSS au Nigéria peut être attribuée à l'échec d'exposé de la politique, la faible base des services médicaux primaires et la manque de supervision.

Mots clés: École santé, connaissance, attitude, usage, directeurs

\section{Introduction}

Children spend a considerable part of their life in school exposed to a variety of environmental, physical, emotional and social influencies. ${ }^{1}$ Therefore to benefit maximally from the educational system children need to be physically, mentally and emotionally healthy while exposure during school hours to various hazards such as physical injury, infections and emotional problems should be minimal if not totally prevented. It is for this reason that the school health program (SHP) was established. A school health program should include the following eight components: (1) parent/community involvement; (2) healthful school environment; (3) health services; (4) health education; (5) physical education; (6) nutrition services; (7) counseling, psychological, and social services; and (8) health promotion for school staff. ${ }^{2,3}$

In developing countries where literacy rate is low and childhood mortality high and for the universal basic education to succeed a good and properly organized school health program is essential. Furthermore in the year 2001 through the use of the Rapid Assessment and Action Planning Process (RAAPP), partnered by World health Organization and Education Development Centre, Nigeria developed an action plan which will serve as a foundation for infrastructure development for school health in Nigeria. One of the action plans is the development of: a comprehensive school health policy at the national level, with appropriate legal support, to guide the management of school health programs amongst others. ${ }^{4}$ However, previous studies from Edo State $^{5,6}$ and Nigeria ${ }^{7,8}$ indicate poor state of the SHP. For a good school health policy to be put in place an evaluation of the current state of the school health program is necessary.

It is in the light of the foregoing that this study was undertaken to assess the knowledge, attitude and practice of school health program by head teachers of primary schools in Egor local Government Area of Edo State Nigeria. The information gathered will be useful in the planning and strengthening of SHP in Edo State.

\section{Materials and Methods}

The study was conducted in Egor local Government Area (LGA) of Edo State between September and December 2004. Egor LGA is located in the State Capital, Benin City. It is $90 \%$ urban and $10 \%$ rural with a total population of 229,681 (2004 projected population) ${ }^{9}$ Egor LGA is divided into 10 geopolitical wards and it is cosmopolitan but the major tribe is Benin. ${ }^{9}$ There are a total of 133 primary schools in Egor LGA made up of 29 public and 104 private schools. All 133 schools were recruited. The subjects were head teachers of these primary schools. Permission to conduct the study was obtained from the Education department of the Local Government Council and informed consent from the head teachers.

A pre-tested questionnaire designed to assess the knowledge, attitude and practice of these head teachers with regards to the school health program was administered by research assistants and collected immediately. Adequate knowledge was determined by good definition plus 5-8 components of school health program. Fair definition plus $2-4$ components of School health program was considered as inadequate knowledge while poor definition plus less than 2 components was considered poor knowledge. The School premises were also inspected to check provision of pipe borne water, sick bay, toilet facilities, ventilation of class rooms and the adequacy of the school environments among other things.

Data was analyzed with the statistical package for social sciences (SPSS 10.0 for windows). Difference between proportions was determined by use of Chi square test.

\section{Results}

All the head teachers (mean age 44years with a range of 27 to 58 years) of the 133 primary schools agreed to participate giving a response rate of $100 \%$. Ninetyfive $(71 \%)$ were females while $38(29 \%)$ were males. Majority of the head teachers $82(61.7 \%)$ where holders of certificates from College of Education, $40 / 133(30.0 \%)$ were graduates from university and $11 / 133(8.3 \%)$ holders of teachers training school certificate.

\section{Knowledge of school health program}

Majority of the head teachers 102/133 (76.7\%) had heard of SHP while 31 (23.3\%) had not. Of the 104 head teachers from private schools $77(74.0 \%)$ had heard of school health program compared to 25/29 $(86.2 \%)$ from public schools. There was no statistical difference in the proportions of those who had heard of the school health program between private and public schools $\left(\chi^{2}=2.18 ; \mathrm{P}>0.05\right)$. None of the 133 head teachers had adequate knowledge of school health program. The proportion of head teachers 
with poor knowledge of SHP from private schools $93.1 \%$ was significantly higher than the proportion from public schools $48.3 \%\left(\chi^{2}=56.86, \mathrm{P}<0.05\right)$. Table 1 shows the level of knowledge of school health programme among the head teachers.

\section{Attitude towards SHP}

All head teachers from both private and public schools had favorable attitude towards SHP as they all expressed it is a desirable and necessary program for the schools. However while 128/133 (96\%) thought it will work, 5 (4\%) thought otherwise.

\section{Practice of components of SHP}

Fifty-one of the $133(38.3 \%)$ schools have SHP. Forty-two of the 104 private schools $(40.4 \%)$ have SHP compared to $9 / 29(31.0 \%)$ public schools. There was no difference in the proportion with SHP between private and public schools $\left(\chi^{2}=0.74 ; \mathrm{P}>0.05\right)$.

Healthy school environment

In 49/104 (47.1\%) of the private schools the pupils are responsible for cleaning the school premises while $55 / 104(52.9 \%)$ employ the services of cleaners. In public schools, $28 / 29(96.6 \%)$ engage the pupils in cleaning the premises.

Adequate water supply defined for the purpose of this study as 24 hours pipe borne water supply was present in $23(17.3 \%)$ of all the schools. All 23 schools were private schools. All the public schools lacked adequate water supply compared to $81(77.9 \%)$ private schools. Table 2 shows the distribution of schools with toilet and hand washing facilities.

Health services

A total of $61 / 133(45.9 \%)$ schools perform medical inspection of pupils on school entry and from time to time. Fifty-three of the $104(51.0 \%)$ private schools compared to $8 / 29(27.6 \%)$ public schools perform medical inspection. There was a significant difference between the proportion of private and public schools that perform medical inspection of their pupils $\left(\chi^{2}=\right.$ 4.88; $\mathrm{P}<0.05)$. The medical inspection was conducted by medical doctors in 25/61 (40.9\%) schools while in 20/61 (45.5\%) and 6/61 (13.6\%) teachers and nurses respectively were responsible.

A total of $42 / 133$ (31.6\%) schools had sick bay for first aid and treatment of minor ailment. There was a significant difference between the proportion of private schools $41 / 104 \quad(39.4 \%)$ with sick bay compared to $1 / 29(3.4 \%)$ in public schools $\left(\chi^{2}=\right.$ $11.11 ; \mathrm{P}<0.05)$

Physical education in school

Majority of the schools $111 / 133(83.5 \%)$ engage their pupils in physical education while in the school. Among the private school 90/104 (86.5\%) engage pupils in physical education compared to 21/29 (72.4\%) among public schools.

\section{Nutrition}

Majority of the schools 123/133 (92.5\%) had school meal policy. The source of school meals is as shown in table 3. However only 22/133 (16.5\%) of the schools undertake medical screening for food handlers/vendors. 21/104 $(20.2 \%)$ private schools compared to $1 / 29(3.4 \%)$ public schools undertake medical screening of food handlers/vendor. The proportion of private schools that screened food handlers and vendors was significantly higher than in public schools.

No counseling service for medical conditions detected in pupils nor health promotion for staff was available in all the schools.

Table 1: Knowledge of school health programme among head teachers in private and public primary schools in Egor Local Government Area, Edo State

\begin{tabular}{llll}
\hline Level of knowledge & Private schools (\%) & Public schools (\%) & Total (\%) \\
\hline Adequate & - & - & - \\
Inadequate & $28(26.9)$ & $15(51.7)$ & $43(32.3)$ \\
Poor & $76(93.1)$ & $14(48.3)$ & $90(67.7)$ \\
\hline Total & $104(100)$ & $29(100)$ & $133(100)$ \\
\hline
\end{tabular}

Table 2: Distribution of primary schools with toilet and hand washing facilities in Egor Local Government Area, Edo State

\begin{tabular}{llllll}
\hline Facility & $\begin{array}{l}\text { Private school } \\
\mathrm{n}=104(\%)\end{array}$ & $\begin{array}{l}\text { Public school } \\
\mathrm{n}=29(\%)\end{array}$ & $\begin{array}{l}\text { Total } \\
\mathrm{n}=133(\%)\end{array}$ & $\mathrm{X}^{2}$ & $\mathrm{p}$ value \\
\hline Toilet & & & & & $>0.05$ \\
None & $27(26.0)$ & $10(34.5)$ & $37(27.7)$ & 1.11 & $>0.05$ \\
Pit & $31(29.8)$ & $12(41.4)$ & $43(32.3)$ & 1.63 & $>0.05$ \\
Water closet & $46(44.2)$ & $7(24.1)$ & $53(40.0)$ & 3.35 & $>0.05$ \\
Hand washing & & & & & \\
Yes & $30(28.8)$ & $4(13.8)$ & $34(25.6)$ & 2.51 & \\
No & $74(71.2)$ & $25(86.2)$ & $99(74.4)$ & & \\
\hline
\end{tabular}


Table 3: Source of meals in primary schools in Egor Local Government Area, Edo State

\begin{tabular}{lll}
\hline Source of meals & $\begin{array}{l}\text { Private school } \\
\mathrm{n}=104 \\
(\%)\end{array}$ & $\begin{array}{l}\text { Public school } \\
\mathrm{n}=29 \\
(\%)\end{array}$ \\
\hline $\begin{array}{l}\text { Home meal } \\
\text { Mobile vendor }\end{array}$ & $56(53.8)$ & $11(37.9)$ \\
$\begin{array}{l}\text { Permanent } \\
\text { vendor }\end{array}$ & $39(30.8)$ & $10(34.5)$ \\
& & $17(58.6)$ \\
\hline
\end{tabular}

\section{Discussion}

The importance of a good and functional SHP as a component of primary health care in the overall development of children and the citizenry of a nation cannot be over emphasized. Various studies in the last 20 years or more in Nigeria have indicated poor status of the school health program. ${ }^{5-8,10-14}$

In spite of the awareness of SHP by majority of head teachers in this study, it is surprising that no head teacher had adequate knowledge of the program. This lack of adequate knowledge may be due to the apparent lack of a concise policy on SHP at the national level and a poor primary health care system. The finding of poor knowledge of the definition and components of the SHP in majority of the head teachers especially in private schools indicate that there is deficiency in the training of teachers at all levels. A review of the studies in Nigeria shows that most of these studies were done by authors from the educational sector and further reveals that the concept of SHP is limited to or centered on medical or health services such as inspection and health education. If this is true it implies that 'would be teachers' are equipped with information albeit limited to medical inspection of simple health issues and health education. This concept which implies that an individual can run SHP in a given school is not only erroneous but far from the current concept of SHP with 8 components. The current concept of the SHP brings together parents, the community, experts and professionals from the education, health and allied sectors on a common platform 'the school' to provide a comprehensive primary health care service to children. This deficient concept of SHP which appears to prevail in Nigeria may play a vital role in the lack of adequate knowledge of SHP among head teachers of primary schools in this study. Furthermore the common practice among private schools to employ graduates who are not professional teachers per se may explain the reason why a significant proportion of head teachers from private than public schools (93.1\% compared to $48.3 \%$ ) have poor knowledge of SHP.

This study shows that the practice of SHP among primary schools in the study location is abysmally poor. Only $38.3 \%$ have SHP in place albeit inadequate. With regards to healthy school environment, all the schools studied clean up their environment regularly. However the practice of certain important aspect of healthy school environment is grossly inadequate. For instance only $17.3 \%$ of the schools (all private schools) had adequate pipe born water supply. The abysmally low percentage of schools with adequate water supply coupled with the fact that no public school had pipe born water testifies to failure of social services at least in the study location. It is therefore not surprising that majority of the schools lacked adequate toilet and hand washing facilities. This situation indicates a poor appraisal of healthy school environment generally but particularly in public schools.

Majority of the schools do not provide adequate health services to their pupils more so in public than private schools. While $45.9 \%$ of all the schools perform medical inspection at entry and from time to time, more private schools $51.0 \%$ compared to $26.7 \%$ public schools provided this health service. Furthermore only $31.6 \%$ mainly private schools have sick bay for the treatment of minor illnesses and emergency first aid. These findings are not only consistent with previous reports from Edo ${ }^{5,6}$ state and other parts of Nigeria ${ }^{7,8,10-14}$ but also shows that the poor status of SHP as regards medical screening and health services in Nigeria has not improved much over the last two decades or more.

Perhaps the only component of the SHP where considerable emphasis has been placed in Nigeria in recent time is nutrition. In recent times because of the need to make the universal basic education (UBE) program of the Federal Government of Nigeria succeed both the federal and state governments have come out to lend support for the provision of school meals for pupils under UBE. It is noteworthy therefore that majority of schools in this study $(92.5 \%)$ have policy for school meal in place. The practice in all schools shows that the source of meals includes home, mobile and permanent food vendors. Only $16.5 \%$ of all the schools screen food handlers while $20.2 \%$ of private schools compared to $3.4 \%$ of public schools practice this very important and statutory public health function. This findings indicate that majority of pupils in the study location particularly in public schools are exposed to public health hazard through consumption of food from unscreened food vendors.

There is no provision of medical counseling and psychological services (through which parent and the community can be brought into the SHP) in all the schools. This is very vital as participation of parents and the community will help in the development and sustainability of the SHP.

In conclusion, 5 years after the development of an action plan to evolve a comprehensive school health policy at the national level in Nigeria, it appears no progress has been made.

\section{Acknowledgment}

We are grateful to Ogunbor Chukwuma and Oyiana I. Gregory who were the research assistants, for their help and the various head teachers for their co operation during the study. 


\section{References}

1. Ademuwagun ZA, Oduntan SO (eds). School health education handbook for teachers and administrators in Nigeria. University Press, Ibadan, 1986; 200 - 204

2. The Texas Guide to School Health Programs. http://www.dshs.state.tx.us/schoolhealth/pgtoc.shtm

3. Virginia school health guidelines. Department of Health, Richmond, 1999

4. Ola JA. School health in Nigeria: national strategies. In: Improving health through schools: national and international strategies. WHO, Geneva, 1999; 81 - 84

5. Ojugo AI. Status of health appraisal services for primary school children in Edo State, Nigeria. International Electronic Journal of Health Education 2005; 8: 146-152

6. Imoge AO. An evaluation of primary health care program in secondary schools in Oredo Local Government Area of Bendel State. Nigerian School Health Journal 1987; 7: $99-104$

7. Ejifugha AU. Awareness of school health services among primary school teachers in Enugu
State. Nigerian School Health Journal 1993; 10: 54-61

8. Nwimo IO. Status of health appraisal services in secondary schools in Owerri education zone, Imo State. Journal of Health and Kinesiology 2001; 2: 94-107

9. Census, National Population Commission, Lagos, 1991

10. Nakajima H. Implementing comprehensive school health education programs. Hygiene 1992; 11: 7-13

11. Nwachukwu CN. Mental health provisions in the national policy on education. The Counsellor 1996; 14: 82-88

12. Nwana OC. Teacher participation in health appraisal. West African Journal of Education 1982; 23: 139-152

13. Nwana OC. Implications of primary health care for school health programme. Nigerian School Health Journal 1988; 8: $21-25$

14. Ogbuji CN. School health services. In: Ezedum CE (ed). School health education. Topmost Press, Nsukka, 2003; 58-72 